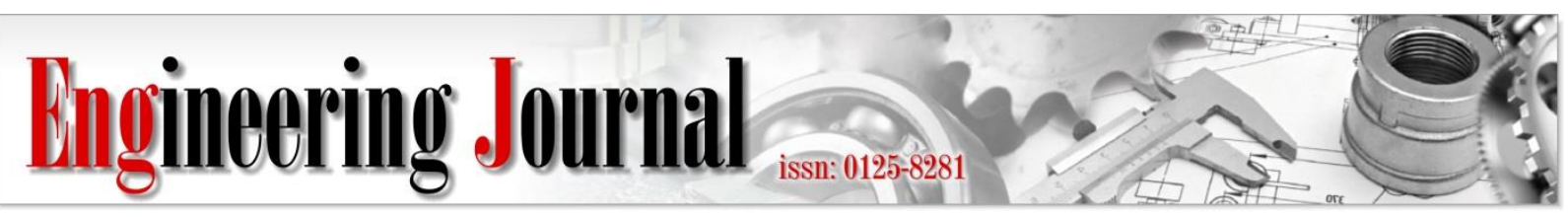

Article

\title{
Concentration Optimization of Sodium Percarbonate as Buffering Catholyte on Stacked Microbial Desalination Cell by Utilizing Tofu Wastewater as a Substrate
}

\author{
Tasya Ayu Febrianaa , Maghfira Risang Khairiza ${ }^{b}$, Raissa Maulinac, Tania Surya Utamid, , \\ Rita Arbianti ${ }^{\mathrm{e}}$, and Heri Hermansyah ${ }^{\mathrm{f}}$ \\ Department of Chemical Engineering, Faculty of Engineering, Universitas Indonesia, Depok 16424, West \\ Java, Indonesia \\ E-mail: atasya.ayu52@che.ui.ac.id, bmaghfira.risang@che.ui.ac.id, craissa.maulina@che.ui.ac.id, \\ dnana@che.ui.ac.id (Corresponding author), ${ }^{e}$ arbianti@che.ui.ac.id, dheri@che.ui.ac.id
}

\begin{abstract}
The objective of this research is to obtain the optimum concentration of Sodium percarbonate (SP) as catholyte which gives the best desalination performance in Stacked Microbial Desalination Cell (SMDC) system using tofu wastewater as a substrate. SMDC is a promising technology for wastewater treatment and water desalination to overcome the problem of water crisis and the use of Sodium percarbonate will prevent $\mathrm{pH}$ imbalance which is one of the major issues in SMDC technology. Four Sodium percarbonate concentration variations of $0.05,0.1,0.15$ and $0.2 \mathrm{M}$ were examined at 50 hours operating time. The optimum performance of Sodium percarbonate is then compared with other commercial catholyte Potassium permanganate. The result of this research is the optimum concentration of sodium percarbonate as a catholyte is at concentration equal to $0.15 \mathrm{M}$ with $1.77 \%$ salt removal in Desalination-Cathode Chamber and $0.82 \%$ salt removal in Desalination-Anode Chamber. Also, the best catholyte is SP in comparison to $\mathrm{KMnO}_{4}$ because it acts as a better electron acceptor (oxidation agent) as well as buffering catholyte with higher value of SDR and TDR equal to $1.2469 \mathrm{~g} /(\mathrm{L} . \mathrm{h})$ and $1.8704 \mathrm{~g} / \mathrm{h}$ respectively.
\end{abstract}

Keywords: Microbial desalination cell, stacked microbial desalination cell, tofu wastewater, sodium percarbonate.

ENGINEERING JOURNAL Volume 24 Issue 4

Received 5 December 2019

Accepted 21 April 2020

Published 31 July 2020

Online at https://engj.org/

DOI:10.4186/ej.2020.24.4.217 


\section{Introduction}

Water is a substance that is very important for the life of living things on this planet. The function of water for life cannot be replaced by other substances. Unfortunately, the clean water crisis is still huge problem not only in Indonesia but also in many countries around the world. According to United Nations Educational, Scientific and Cultural Organization (UNESCO), at present, an estimated 3.6 billion people, nearly half the global population, live in areas potentially water-scarce at least one month per year, and this population could increase to come 4.8 billion to 5.7 billion by 2050 [1]. The largest source of water on Earth is Seawater. Of all the water resources on Earth, $97 \%$ is salt water and only 3\% is fresh water, more than two-thirds of which are in the form of ice in glaciers and polar ice [2]. This problem of the clean water crisis can be overcome by desalinating the most abundant source of water in the area, which is the seawater.

One method that has the potential in desalinating seawater by utilizing organic matter and the metabolism from microorganisms is using the Microbial Desalination Cell (MDC) method. MDC is one of the new technologies developed from the Microbial Fuel Cell (MFC) method, which has the ability to desalinate seawater to produce electrical energy. Furthermore, to improve the desalination process on MDC technology, a multilevel desalination system is created, known as Stacked Microbial Desalination Cell (SMDC) [3].

MDC was first established by Cao et al., (2009) with the concept of modifying microbial fuel cell (MFC) by inserting a desalination chamber constructed with a pair of Anion Exchange Membrane (AEM) and Cation Exchange Membrane (CEM) between the anode and cathode. Thus, the reactor used consisted of three chambers with a mixed bacterial culture taken from the MFC anode in sodium acetate substrate in the anode chamber and the cathode chamber was fed a ferricyanide catholyte and $\mathrm{NaCl}$ solution in the middle chamber. This first MDC produced $90 \%$ salt removal [4]. This research was continued to develop by Menhanna et al., (2010) who experimented MDC using the same anolyte and catholyte as the previous research but made a difference by adding platinum catalyst on the cathode which results in greater desalination capabilities than previous studies, but desalinated water does not adequately meet the quality standards for drinking water [5].

Then, Luo et al., (2011) experimented on desalination by utilizing domestic wastewater as a substrate and used buffer phosphate solution as catholyte. Based on this experiment, $66 \%$ salt removal was obtained [6]. Furthermore, the MDC study in the same year was also carried out by Qu et al., (2011) which was only able to obtained $34 \%$ salt removal and able to regulate $\mathrm{pH}$ imbalances in the cathode and anode chambers and inhibit bacterial metabolism. Qu et al., (2011) conducted electrolyte re-circulation to control changes in $\mathrm{pH}$ in the anode and cathode chambers by using a substrate in the form of domestic wastewater and catholyte in the form of a phosphate buffer solution [7].

After being invented in 2009, the MDC technology has received a significant improvement in structure and performance. Chen et al., (2011) for the first time, established a stacked MDC with sodium acetate as a substrate and investigated the influence of stack number on desalination performance. The SMDC constructed by Chen et al., consisted of anode chamber, cathode chamber and stacked desalination cells. The stacked desalination cells were composed of two desalination chamber and one concentrated chamber that were separated by AEM and CEM. This study proved to be an effective approach to increase the desalination rate about 1.4 times as much as that of single-desalination-chambered MDC [3].

Then, Kim \& Logan (2011) improved MDC performance by using electrodialysis stack consisting of 5 pairs or desalting and concentrating cells. With the usage of the same substrate as Chen et al., when 4 stacked MDCs were used in series, 44\% Salt Removal was obtained [8]. Next, Zuo et al., (2014) made a large-scale stacked MDC packed with mixed ion-exchange resins with the same substrate that has been used previously in SDMC researches and achieved a considerable desalination rate (95.4 mg/h), suggesting promising application for desalination through deriving biochemical electricity from wastewater [9].

Then, in 2018, Ziaedini et al., used phenolcontaminated water as a substrate as synthetic industrial wastewater. Ziaedini et al., adapted the regular 5chambered SMDC invented by Chen et al., (2011) however they modified the flow configuration (Series or parallel) and the inter-membrane distance in SMDCs. it can be concluded that the different behavior of the SMDC at high and low $\mathrm{NaCl}$ concentrations should be taken into consideration in order to optimize the design and operation of these desalination systems [10].

In this research, tofu wastewater is used as a substrate as it contains high organic compounds [11] and because presently, tofu wastewater is thrown away and accumulated in the environment which contaminates the clean water source. Sodium percarbonate (SP) is used as the catholyte in this research due to its capability of providing excellent buffer capacity for $\mathrm{pH}$ stabilization in the desalination process [12] as well as functions as a lowcost catholyte [13].

This research optimizes the SMDC system with a bioreactor consists of three blocks (anode chamber, cathode chamber, and stacked desalination cells which are composed of 2 desalination chambers and a concentrated chamber that were spaced by AEM and CEM). The volume of the reactor is $2250 \mathrm{ml}: 750 \mathrm{ml}: 750 \mathrm{ml}: 750 \mathrm{ml}$, with Sodium percarbonate as catholyte with the concentration variations of $0.05 \mathrm{M}, 0.1 \mathrm{M}, 0.15 \mathrm{M}$ and 0.2 $\mathrm{M}$ and a model of seawater using $\mathrm{NaCl}$ solution $30 \mathrm{~g} / \mathrm{L}$. In addition, the performance of sodium percarbonate in the optimum condition is compared with a commercial catholyte which is often used in MDC research, Potassium permanganate. 


\section{Equipment and Materials}

\subsection{Equipment}

The equipment used for the desalination to take place is the five-chamber SMDC reactor where each chamber is separated by Ion Exchange Membrane (IEM) consists of Anion Exchange Membrane (AEM) and Cation Exchange Membrane (CEM) to selectively transport ions from one solution to another. The anode used is graphite rod and stainless steel mesh, and the cathode used in this research is carbon fiber cloth. The electrical circuit consisted of 10 ohm resistor, electric cable and clamps. Other equipment such as watch glass, measuring glass beaker, spatula, pipette, funnel, cuvette and hot plate stirrer as heating device for making solution are used in the experimental process. In addition, conductivity meter CD-4301 is used to measure the conductivity of a salt solution, $\mathrm{pH}$ meter is used to measure the $\mathrm{pH}$ of the electrolyte solutions, spectrophotometer Bell M90 is used to measure absorbance and digital scale is used to weigh the mass of the material.

\subsection{Materials}

The main material used is Sodium percarbonate as a catholyte that being examined. Potassium permanganate is used as a comparative catholyte. Then, distilled water is used as solvents and diluents. $\mathrm{NaCl}$ is used for making seawater models and membrane preparation. $\mathrm{HCl}$ and $\mathrm{NaOH}$ is used for electrode preparation, $\mathrm{H}_{2} \mathrm{SO}_{4}$ is used for soaking stainless steel mesh, $\mathrm{NaH}_{2} \mathrm{PO}_{4}, \mathrm{Na}_{2} \mathrm{HPO}_{4}$, $\mathrm{KH}_{2} \mathrm{PO}_{4} / \mathrm{K}_{2} \mathrm{HPO}_{4}$ are acid and base solutions used for making buffer phosphate $\mathrm{pH}$ 7. More importantly, tofu wastewater model is used as the substrate or the anolyte in this research which are made using soy beans, distilled water, and vinegar $\left(\mathrm{CH}_{3} \mathrm{COOH}\right)$.

\section{Methods}

\subsection{SMDC Reactor Design}

Based on the figure below, the design of this SMDC reactor consists of five-chamber reactor; Anode chamber, Cathode Chamber, two desalination chambers and one concentrated chamber. The actual volume of the SMDC reactor is $2250 \mathrm{ml}: 750 \mathrm{ml}: 750 \mathrm{ml}: 750 \mathrm{ml}$ for the Anode chamber, desalination chamber, concentrated chamber and cathode chamber respectively. In this research, 10 ohm resistor is used.

In this SMDC reactor also consists of Anion Exchange Membrane (AEM) inserted between the anode chamber and the desalination chamber (D), with Cation Exchange Membrane (CEM) inserted between the cathode chamber and the desalination chamber (D). However, because this reactor is stacked MDC reactor, there is a concentrated chamber $(\mathrm{C})$ in between the two desalination chambers separated by AEM and CEM as it is shown in the figure. Aside from that, the reactor also consists of electrodes (A: anodes, B: cathodes).

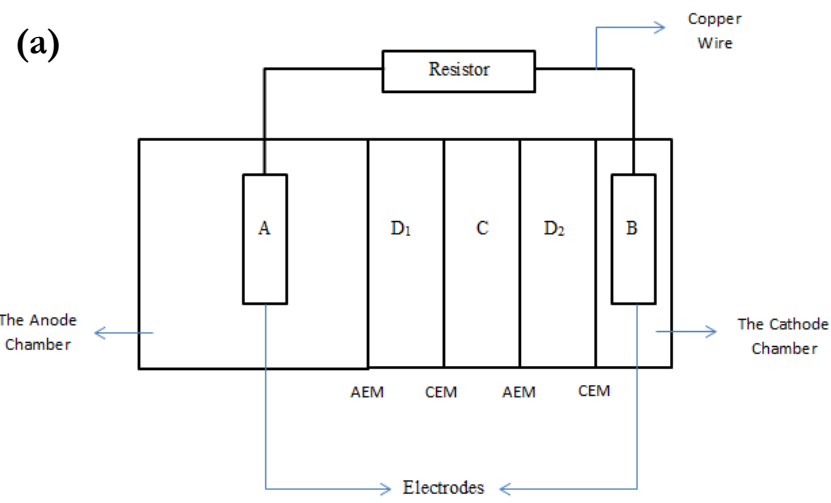

(b)

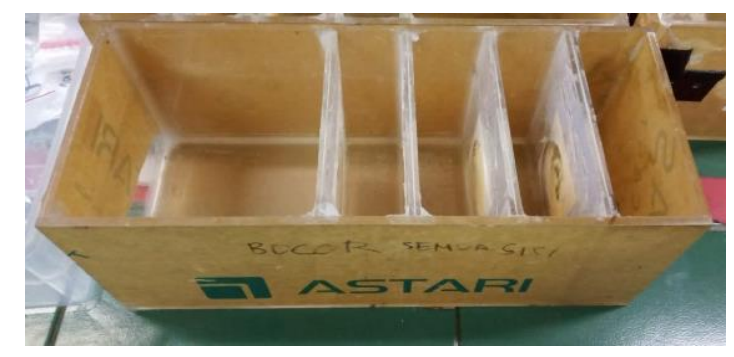

Fig. 1. (a) SMDC reactor design; (b) The five-chamber reactor.

Referring to Fig. 1(a), several terms are going to be used in the analysis. Where Desalination-Anode Chamber (D-Anode) is the term used for $\mathrm{D}_{1}$ as it is the desalination chamber adjacent to the anode chamber; DesalinationCathode Chamber (D-Cathode) is the term used for $\mathrm{D}_{2}$ as it is the desalination chamber adjacent to the cathode chamber.

\subsection{Preparation of Electrode}

Electrodes preparation includes the activation of graphite rod electrode, stainless steel mesh and carbon fiber cloth (CFC).

\subsubsection{Preparation of graphite rod}

The preparation of the graphite rod is done by immersing the electrode into $0.1 \mathrm{M} \mathrm{HCl}$ solution for 24 hours, then rinse with distilled water. Then, immerse the electrode back into $0.1 \mathrm{M} \mathrm{NaOH}$ solution for 24 hours then rinse with distilled water. Next, immerse the electrode into the solution of distilled water until it will be used.

\subsubsection{Preparation of stainless steel mesh}

The preparation of Stainless Steel Mesh is done by immersing the stainless steel mesh into $1 \mathrm{M} \mathrm{H}_{2} \mathrm{SO}_{4}$ solution for 24 hours. Keep it immersed until it will be used.

\subsubsection{Preparation of $\mathrm{CFC}$}

The preparation of $\mathrm{CFC}$ is done by immersing the electrode into $0.1 \mathrm{M} \mathrm{HCl}$ solution for 24 hours, then rinse with distilled water. Then, immerse the electrode back into $0.1 \mathrm{M} \mathrm{NaOH}$ solution for 24 hours then rinse with 
distilled water. Immerse the electrode into the solution of distilled water until it will be used.

\subsection{Preparation of Membrane}

The membranes in this research are AEM and CEM, the preparation method for these membranes is carried out according to the activation instruction of Membrane International, which is by immersing AEM and CEM into $5 \% \mathrm{NaCl}$ solution at temperature of $40^{\circ} \mathrm{C}$. The membranes should be kept immersed until they are ready to use

\subsection{Preparation of Anolyte}

The anolyte used in this research is tofu wastewater model where the $\mathrm{pH}$ and the optical density (OD) will be measured using $\mathrm{pH}$ meter and spectrophotometer respectively, when an experiment will be conducted.

The steps of making the tofu wastewater model are firstly, weigh $270 \mathrm{~g}$ of dry soybeans. Then, soak the dry soybeans in water for 3 hours. Then, rinse the soybeans that have been soaked with distilled water (do this step 3 times). Next, blend the soybeans using blender with addition of distilled water to soybeans ratio $(476 \mathrm{ml}: 270$ g). Then, boil the blended soybeans using $635 \mathrm{ml}$ distilled water. Add $318 \mathrm{ml}$ of distilled water into the mixture every time the mixture raises and boils (until it raises 4 times). Then, filter the mixture to separate the curd from the milk using filter cloth, and weigh the filtered milk in ml. Add $\mathrm{CH}_{3} \mathrm{COOH}$ into the milk with milk to $\mathrm{CH}_{3} \mathrm{COOH}$ ratio (10 L soymilk : $\left.100 \mathrm{ml} \mathrm{CH}_{3} \mathrm{COOH}\right)$. Leave it for 30 minutes. Then, conduct another filtration, separating the curd from the water using filter cloth. The wastewater is then ready to use for the experiment.

\subsection{Preparation of Catholyte}

The catholyte that will be tested and studied is Sodium percarbonate $\left(2 \mathrm{Na}_{2} \mathrm{CO}_{3} \cdot 3 \mathrm{H}_{2} \mathrm{O}_{2}\right)$ with concentration variations of $0.05 \mathrm{M}, 0.1 \mathrm{M}, 0.12 \mathrm{M}$ and $0.2 \mathrm{M}$, whereas Potassium permanganate $\left(\mathrm{KMnO}_{4}\right)$ is tested at a concentration equal to the optimum concentration of SP that is obtained from the experiment of SP concentration variations.

\subsection{Preparation of Seawater Model}

The preparation of seawater model is by using $\mathrm{NaCl}$ solution with a concentration at $35 \mathrm{~g} / \mathrm{L}$.

\subsection{Determination of SMDC Operating Time}

This step is carried out by preparing 1 unit of SMDC reactor, set up the electrodes and the membranes according to the arrangement shown in Fig. 1(a). put 1500 $\mathrm{ml}$ tofu wastewater and $750 \mathrm{ml}$ buffer phosphate $0.1 \mathrm{M}$ pH 7 into the anode chamber into the SMDC unit. Then, Put $750 \mathrm{ml}$ Sodium percarbonate with concentration 0.1 $\mathrm{M}$, the cathode chamber in SMDC reactor unit, put 750 $\mathrm{ml} 35 \mathrm{~g} / 1 \mathrm{NaCl}$ solution into the concentrated chamber and desalination chambers in SMDC reactor unit. Measure the $\mathrm{pH}$ of tofu wastewater and sodium percarbonate in the beginning of the experiment. Then, install conductivity meter to measure the conductivity of $\mathrm{NaCl}$ solution. Stop the experiment after 72 hours. Finally, measure the $\mathrm{pH}$ of tofu wastewater and sodium percarbonate at the end of an experiment. The operating time is determined based on the salinity profile.

\subsection{SMDC Experiment with Concentration Variation of Catholyte Sodium Percarbonate}

The experiment is carried out in a Stacked Microbial Desalination Cell (SMDC) Reactor consisting of 5 chambers, namely the anode chamber, two desalination chambers, the concentrated chamber placed between the two desalination chambers, and the cathode chamber. The volume ratio of the reactor is $2250 \mathrm{ml}: 750 \mathrm{ml}: 750 \mathrm{ml}$ : $750 \mathrm{ml}$ for Anode chamber, desalination chamber, concentrated chamber and cathode chamber respectively.

This experiment is carried out with variations in Sodium percarbonate concentrations of $0.05 \mathrm{M}, 0.1 \mathrm{M}$, $0.15 \mathrm{M}$ and $0.2 \mathrm{M}$. The experiment starts off with preparing the SMDC reactor and setting up the electrodes arrangement. Then, put $2250 \mathrm{ml}$ tofu wastewater into the anode chamber, $750 \mathrm{ml}$ sodium percarbonate into the cathode chamber, $750 \mathrm{ml}$ of $35 \mathrm{~g} / 1 \mathrm{NaCl}$ solution into the desalination and the concentrated chambers. Then measure the initial and final $\mathrm{pH}$ of anolyte and catholyte, the conductance of the desalination and concentrated chambers for 50 hours of operation. Then, find the optimum concentration of Sodium Percarbonate.

\subsection{Performance Comparison of Catholytes Between Sodium Percarbonate and Potassium Permanganate}

The optimum performance of Sodium percarbonate that is obtained from the previous step is then compared with the performance of catholyte Potassium permanganate with a concentration equal to the optimum concentration of Sodium percarbonate. In this experiment, $2250 \mathrm{ml}$ of tofu waste water is added to the anode chamber, $275 \mathrm{ml}$ of potassium permanganate solution into the cathode chamber, adding $375 \mathrm{ml}$ of $0.1 \mathrm{M}$ buffer phosphate $\mathrm{pH} 7$ into the cathode chamber, and $750 \mathrm{ml}$ of $35 \mathrm{~g} / 1 \mathrm{NaCl}$ solution is added into the concentrated and desalination chambers. Finally, measure the initial and final $\mathrm{pH}$ of the anolyte and catholyte, measure the conductivity of $\mathrm{NaCl}$ solution and compare the result.

\subsection{Analysis}

In this research, the conductivity value of the salt solution is obtained which is measured by a conductivity meter. Every data observation of conductance, the data is collected three times. Based on that data of conductivity, the concentration of $\mathrm{NaCl}$ solution which shows a decrease in salt concentration can be obtained. Moreover, the $\mathrm{pH}$ of the solution is measured by $\mathrm{pH}$ meter for analyzing the ion exchange that occurs during the desalination. $\mathrm{pH}$ data collection is done two times. 


\subsubsection{Salt Removal}

Salt removal (SR) represents the percentage of the lost salt concentration compared to the initial salt concentration. The salt removal can be calculated using Eq. (1) [14].

$$
S R=\frac{C_{o}-C_{i}}{C_{o}} \times 100 \%
$$

where SR is salt removal, $\mathrm{C}_{\mathrm{o}}$ is the initial salt concentration $(\mathrm{g} / \mathrm{l})$ and $\mathrm{C}_{\mathrm{i}}$ is the final salt concentration $(\mathrm{g} / \mathrm{l})$.

\subsubsection{Specific desalination rate (SDR) and Total desalination rate (TDR)}

In order to obtain the SDR and TDR, the desalination ratio $(\eta)$ should be calculated first. The desalination ratio of an SMDC with a number of desalination chambers of $\mathrm{N}$ at a certain desalination time can be obtained by the following equation:

$$
\eta=\frac{V_{1} \times \sigma_{1}+V_{2} \times \sigma_{2}+\cdots+V_{N} \times \sigma_{N}}{\left(V_{1}+V_{2}+\cdots+V_{N}\right) \times \sigma_{0}}
$$

Here, $\mathrm{V}_{K}$ and $\sigma_{\mathrm{K}}(\mathrm{K}=1,2, \ldots, \mathrm{N})$ stand for the volume and conductivity of salt solution in the Kth desalination chamber at a certain desalination time, respectively, and $\sigma_{0}$ is the conductivity of the initial salt solution.

When one desalination cycle terminated both the specific desalination rate (SDR) based on salt solution volume (on the basis of desalination chamber volume 750 $\mathrm{ml})$ ) and the total desalination rate (TDR) were calculated using Eq. (3) and (4). The former tells $\mathrm{NaCl}$ removal rate per unit desalinated water volume and the latter shows the total $\mathrm{NaCl}$ removal rate in a whole SMDC.

$$
\begin{gathered}
S D R=\frac{\eta \times C_{0}}{t} \\
\mathrm{TDR}=\frac{\eta \times C_{0} \times\left(V_{1}+V_{2}+\cdots+V_{N}\right)}{t}
\end{gathered}
$$

where $\eta$ and $T$ are the desalination ratio and time respectively when one desalination cycle terminated. $\mathrm{C}_{0}$ is the concentration of the initial $\mathrm{NaCl}$ solution.

\section{Result and Discussion}

This section describes the result of the research as well as the discussion of the analysis of the result obtained. The operating time is determined by conducting an SMDC experiment and analyzed quantitatively by looking at the decreasing of salinity of the desalination chambers. Also, the salt removal is analyzed in variations of concentration of catholyte Sodium percarbonate. Furthermore, desalination performance is analyzed and being compared between the catholytes Sodium percarbonate and Potassium permanganate at the same concentration of $0.15 \mathrm{M}$. Desalination rate at the optimum condition is also quantitatively analyzed as well as the change in $\mathrm{pH}$ in cathode and anode chambers.

\subsection{Determination of SMDC Operating Time}

Determination of SMDC operating time is conducted to determine the final/ end time of the optimal SMDC system operation for desalination that is operated on batch system. Desalination performance can be identified by looking at the decreased salinity profile in respect to time. Therefore, it is important to obtain the salinity of the saline water in both D-Cathode and D-Anode Chambers over a period of time.

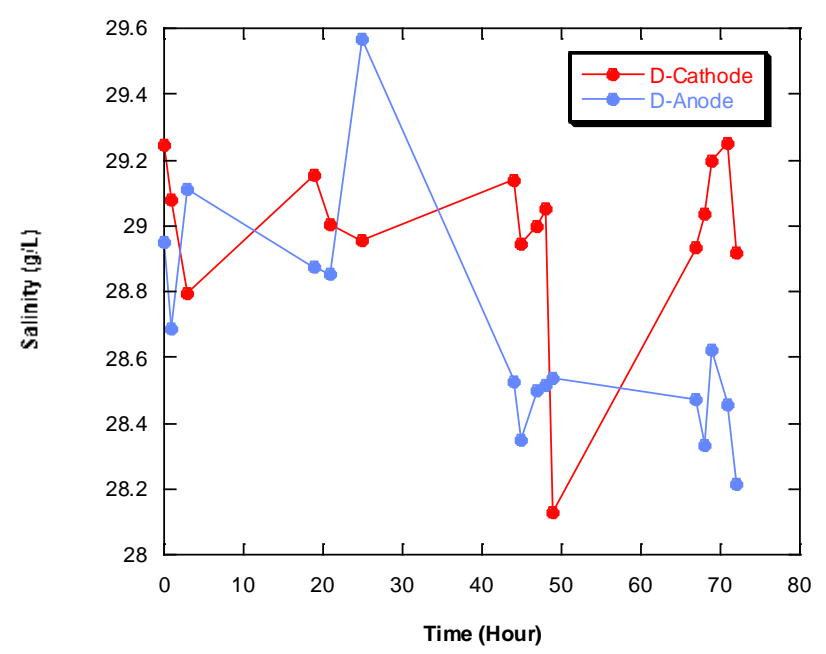

Fig. 2. Salinity profile with respect to time of SMDC operation.

Figure 2 illustrates the concentration of salt over a period of time in SMDC operation within the D-Cathode and D-Anode Chambers of SMDC reactor. From the figure above, it is obtained that over a period of time, the salinity of the saline water on both chambers is decreasing even though there is a slight fluctuation in between. Specifically, both desalination chambers experience a decrease in salinity from the beginning of the process $($ time $=0)$ until the time reached to 49 hours of operation where the salinity decreases from $29.25 \mathrm{~g} / \mathrm{L}$ to $28.13 \mathrm{~g} / \mathrm{L}$ in the D-Cathode Chamber and decreases from $28.95 \mathrm{~g} / \mathrm{L}$ to $28.53 \mathrm{~g} / \mathrm{L}$ in $\mathrm{D}$-Anode Chamber . Then, from time equal to 67 hours until 69 hours, the salinity increases which might be due to back diffusion, then eventually decreases again until the $72^{\text {nd }}$ hour.

According to the principle of an MDC, electric current is one of the driving forces of desalination [15]. This statement is also stated by Mehanna et al., (2010) in his research, that desalination process is bounded by the electrical voltage generated by the bacteria [5]. A decrease in salinity that is illustrated in Fig. 2 is possible to occur due to the electrical voltage obtained in the SMDC system generated by the bacteria in tofu wastewater. The smaller the voltage, the smaller the decrease in salinity gets.

In this experiment, the determination of operating time is determined when the desalination performance in SMDC system has not reached the phenomenon of backdiffusion. Because theoretically, current generation drives ion movement from the desalination compartment to the concentrated compartment, against back-diffusion [16]. In Figure 3 salinity decreases from $t=0$ hours to $t=49$ hours 
with flight fluctuation in between, and then back-diffusion starts to occur at $\mathrm{t}=67$ hour. Based on the research done by Ping $e$ e al. 2013, the application of operating time over a longer period does not result in a significant decrease in salinity [15]. As it was mentioned before, significant decrease in salinity in this research occurs between $\mathrm{t}=0$ until $\mathrm{t}=49$ hours, hence, it is decided that the efficient operating time for SMDC is 50 hours.

\subsection{SMDC Experiment with Concentration Variation of Catholyte Sodium Percarbonate}

This experiment is carried out with variations in the concentration of Sodium percarbonate as a catholyte in the cathode chamber of SMDC reactor system. The variations of concentration used in this experiment are $0.05 \mathrm{M}, 0.1 \mathrm{M}, 0.15 \mathrm{M}$ and $0.2 \mathrm{M}$. The objective of this experiment is to examine the effects of different concentrations of Sodium percarbonate in cathode chamber to the desalination performance in SMDC system. Furthermore, this experiment is conducted to obtain the optimum concentration that gives the optimum desalination performance in a form of the salt removal percentage obtained in the SMDC operation system.

The following is the result obtained from the experiment with concentration variations of catholyte Sodium percarbonate for 50 hours operating time:

Table 1. Salt removal obtained from various concentration of $\mathrm{SP}$ at $\mathrm{t}=50$ hours.

\begin{tabular}{cccc}
\hline \multirow{2}{*}{ No } & Concentration & \multicolumn{2}{c}{ Salt Removal (\%) } \\
\cline { 3 - 4 } & Variation of SP & D-Cathode & D-Anode \\
\hline $\mathbf{1}$ & $0.05 \mathrm{M}$ & 0.79 & 1.14 \\
$\mathbf{2}$ & $0.1 \mathrm{M}$ & 1.15 & 1.22 \\
$\mathbf{3}$ & $0.15 \mathrm{M}$ & 1.77 & 0.82 \\
$\mathbf{4}$ & $0.2 \mathrm{M}$ & -0.72 & -0.99 \\
\hline
\end{tabular}

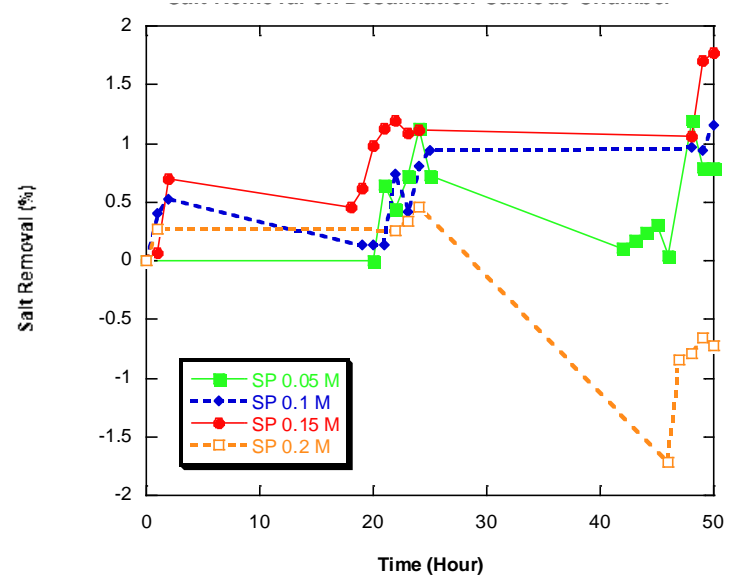

Fig. 3. Salt Removal (SR) result in SMDC experiment with concentration variation of Sodium percarbonate for $50 \mathrm{~h}$ operation in Desalination-Cathode Chamber.

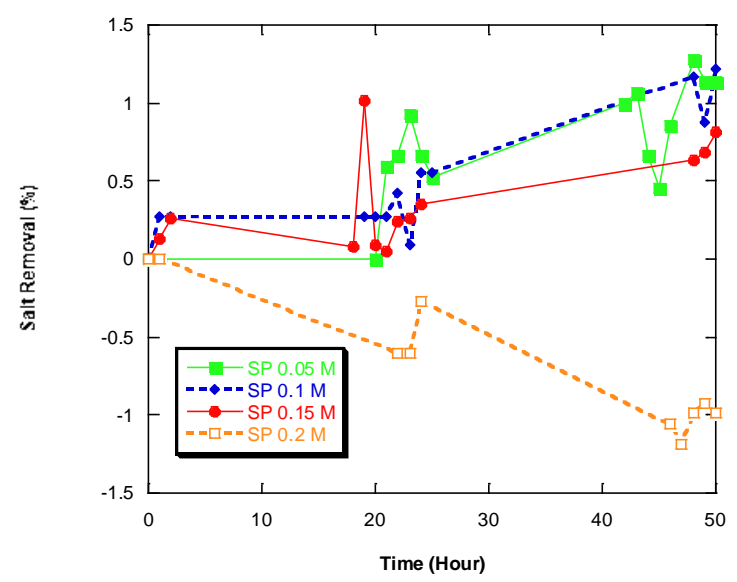

Fig. 4. Salt removal (SR) result in SMDC experiment with concentration variation of Sodium percarbonate for 50 hours operation in Desalination-Anode Chamber.

Based on the Table 1 and Figs. 3 and 4, the two best results of salt removal are obtained from concentration variations of $0.1 \mathrm{M}$ and $0.15 \mathrm{M}$ of Sodium percarbonate (SP). At concentration of $0.1 \mathrm{M}$, the salt removal obtained in the Desalination-Cathode (D-Cathode) and Desalination-Anode (D-Anode) Chambers are $1.15 \%$ and $1.22 \%$ respectively. At this concentration, SMDC system was able to decrease the salinity in the D-Cathode Chamber from $28.65 \mathrm{~g} / \mathrm{L}$ to $28.32 \mathrm{~g} / \mathrm{L}$ and a decrease in salinity from $28.55 \mathrm{~g} / \mathrm{L}$ to $28.17 \mathrm{~g} / \mathrm{L}$ in the $\mathrm{D}$-Anode Chamber.

Whereas at concentration of $0.15 \mathrm{M}$, the salt removal obtained in the Desalination-Cathode and DesalinationAnode Chambers are $1.77 \%$ and $0.82 \%$ respectively. At this concentration, SMDC system was able to reduce the salinity in the D-Cathode camber from $29.03 \mathrm{~g} / \mathrm{L}$ to 28.52 $\mathrm{g} / \mathrm{L}$ and a decrease in salinity from $28.53 \mathrm{~g} / \mathrm{L}$ to $28.29 \mathrm{~g} / \mathrm{L}$ in the D-Anode Chamber. From these results, it can be concluded that the optimum condition in this experiment is obtained at a variation concentration of SP equal to 0.15 $\mathrm{M}$, with a total salt removal of $2.59 \%$ and an average of salt removal equal to $1.295 \%$, that is higher than that of the result obtained at $0.1 \mathrm{M}$ of SP.

First of all, electrodes play a very significant role in the operation of SMDC since power output substantially depends on the potential difference between the anode and the cathode [17]. Materials used as electrodes basically should have high electrical conductivity [18]. Kaabi et al (2017) found that the maximum capacity of the electrode obtained at high concentration of electrolyte. In other words, higher concentration of electrolyte leads to higher capacity of the electrode which related to higher conductivity [19]. However, the result obtained from this experiment is not in accordance to the theory stated by Kaabi et al.

The result shows that the value of SP concentration of $0.2 \mathrm{M}$ has a salt removal lower than that of the concentration of SP at $0.05 \mathrm{M}, 0.1 \mathrm{M}$ and $0.15 \mathrm{M}$. The salt removal obtained from SP $0.2 \mathrm{M}$ shows negative values which indicate that there is an addition of salt into the desalination chambers instead of salt removal. This phenomenon occurs due to a factor that influences the 
efficiency of SMDC system such as back diffusion of ions from the high concentrated area to the lower concentrated area [13].

At some period of time, the high salinity in the concentrated chamber and low salinity in the desalination chambers create a concentration gradient, which may play role in back-diffusion mechanism which contributed by molecule transport. In the molecule transport, a higher concentration gradient leads to higher osmotic pressure and thus more water transport from the concentrated chamber to the desalination chambers, which drives more molecules to transfer to the desalinated chamber [16].

\subsection{Performance Comparison of Catholyte Sodium Percarbonate and Potassium Permanganate}

According to the previous experiment, the optimum condition is obtained from Sodium percarbonate with a concentration of $0.15 \mathrm{M}$. Therefore, the desalination performance of the Sodium percarbonate optimum concentration $(0.15 \mathrm{M})$ is compared with another commercial catholyte in MDC research, Potassium Permanganate with the same concentration of $0.15 \mathrm{M}$. The objective of this experiment is to examine the desalination performance of both catholytes in SMDC system.

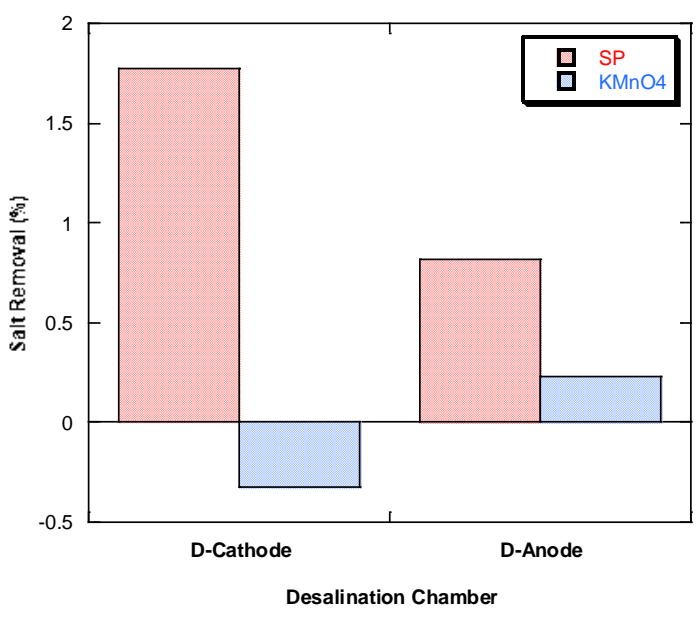

Fig. 5. Comparison of salt removal between catholytes SP and $\mathrm{KMnO}_{4}$ on both Desalination-Cathode and Desalintion-Anode Chambers.

Figure 5 illustrates the desalination performance comparison between catholytes Sodium percarbonate and potassium permanganate. Based on the graph, the salt removal in SMDC experiment using catholyte Sodium percarbonate at its optimum concentration is higher compared to SMDC using catholyte $\mathrm{KMnO}_{4}$. The salt removal obtained at SP $0.15 \mathrm{M}$ is $1.77 \%$ in the D-Cathode chamber and $0.82 \%$ in D-Anode Chamber. Whereas in the case of using $\mathrm{KMnO} 4$ as a catholyte, the salt removal obtained at $0.15 \mathrm{M}$ in the D-Cathode chamber shows a negative value of $-0.32 \%$, which means the result rather shows there's an absence in salt removal, in contrast, there is a slight salt removal of $0.23 \%$ in the D-Anode chamber. (a)

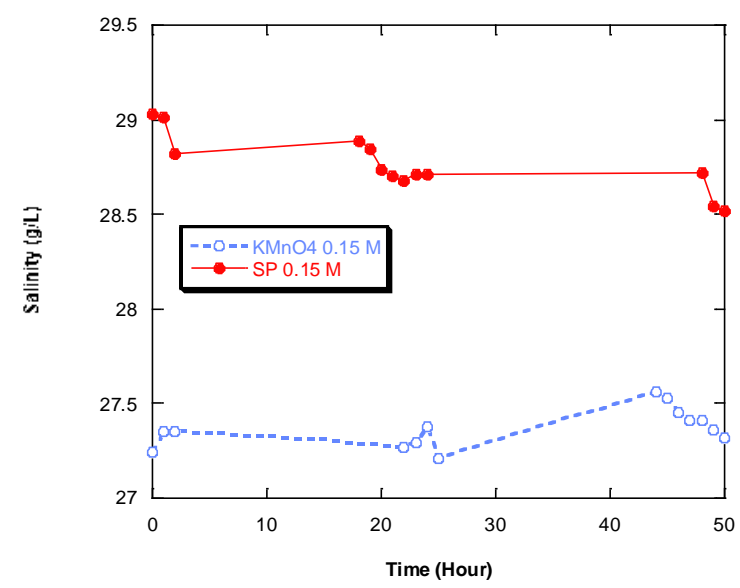

(b)

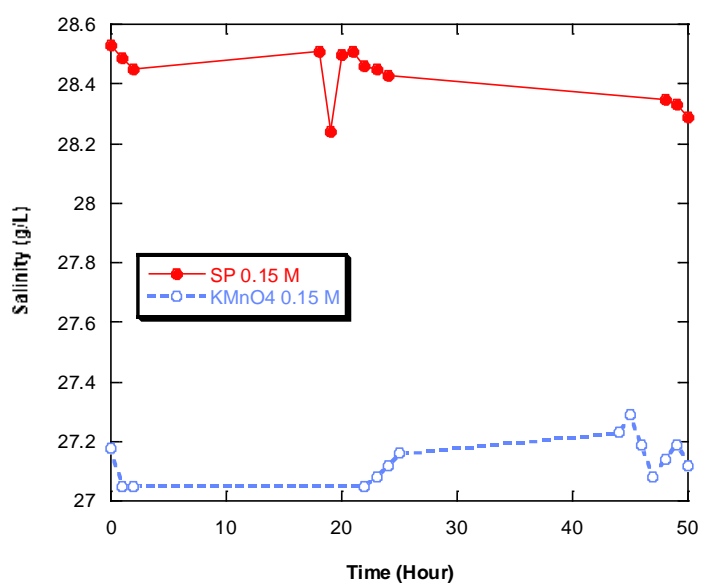

Fig. 6. Comparison of Salinity between Catholytes SP and $\mathrm{KMnO}_{4}$ (a) in D-Cathode Chamber, (b) in D-Anode Chamber.

Furthermore, with the salt removal percentage that has been obtained, Fig. 6 above illustrate the salinity on both D-Cathode and D-Anode chambers on SMDC experiment using both catholytes $\mathrm{SP}$ and $\mathrm{KMnO} 4$ at 0.15 $\mathrm{M}$ concentration. Figure 6(a) shows that the salinity in DCathode chamber when using catholyte SP decreases from $29.03 \mathrm{~g} / \mathrm{L}$ to $28.52 \mathrm{~g} / \mathrm{L}$ and using catholyte $\mathrm{KMnO}_{4}$ the salinity experienced an increase rather than a decrease from $27.24 \mathrm{~g} / \mathrm{L}$ to $27.32 \mathrm{~g} / \mathrm{L}$, which explains why the salt removal was negative in the case of $\mathrm{KMnO} 4$ in the $\mathrm{D}$ Cathode chamber. Figure 6(b) shows the salinity in DAnode chamber decreases from $28.53 \mathrm{~g} / \mathrm{L}$ to $28.29 \mathrm{~g} / \mathrm{L}$ using SP and a slight decrease from $27.18 \mathrm{~g} / \mathrm{L}$ to 27.12 $\mathrm{g} / \mathrm{L}$ using $\mathrm{KMnO}_{4}$. Overall, SMDC experiment using Sodium percarbonate as a catholyte shows greater result in the reduction of salinity of the saltwater compared to $\mathrm{KMnO}_{4}$.

The flow of electrons in an electrochemical system is triggered by the potential difference between the anode and the cathode. Potential difference between the anode and the cathode can be measured under standard conditions - that is, with all species in their standard states ( $1 \mathrm{M}$ for solutions and pressures of $1 \mathrm{~atm}$ at $25^{\circ} \mathrm{C}$ ). The higher the cell's standard state potential, the higher the 
potential difference (voltage) produced. The standard cell potential can be calculated using the following equation.

$$
\mathrm{E}_{\text {cell }}^{\mathrm{o}}=\mathrm{E}^{\mathrm{o}} \text { red;cathode }-\mathrm{E}^{\mathrm{o}} \text { red;anode }
$$

where $\mathrm{E}^{\mathrm{o}}$ cell is the standard cell potential (volt), $\mathrm{E}_{\text {red;cathode }}^{\mathrm{r}}$ is the reduction potential for the reduction half-reaction at cathode and $\mathrm{E}^{\circ}$ red;anode is the reduction potential for the reverse of the oxidation half-reaction at anode. In this experiment, as the anolyte used is the same for both cases, it can be said that the $\mathrm{E}^{\circ}$ red;anode value is the same, thus based on Eq. (5), the higher the value of $\mathrm{E}^{\circ}$ red;cathode, the higher the Eo ${ }^{o}$ cell. Petrucci et al. (2010) states that high value of the reduction potential of a cathode indicates the tendency of a chemical species to be reduced and to capture electrons (oxidizing agent) [20].

The decomposition of SP results in $\mathrm{HO}_{2}$ - ions and the decomposition of $\mathrm{KMnO}_{4}$ results in $\mathrm{MNO}^{-}$- ions which act as electron acceptors with cathodic reactions that are represented in Eq. (6) [21] and Eq. (7) [22] that occur in basic condition.

$$
\begin{gathered}
\mathrm{HO}_{2^{-}}+\mathrm{H}_{2} \mathrm{O}+2 \mathrm{e}^{-} \rightarrow 3 \mathrm{OH}^{-}, \mathrm{E}_{0}=+0.878 \mathrm{~V} \text { (pH base) (6) } \\
\mathrm{MnO}_{4^{-}}+2 \mathrm{H}_{2} \mathrm{O}+3 \mathrm{e}^{-} \rightarrow \mathrm{MnO}_{2}+4 \mathrm{OH}^{-} \\
\mathrm{E}_{0}=+0.59 \mathrm{~V}(\mathrm{pH} \text { base })
\end{gathered}
$$

In alkaline condition as oxidizing agents, $\mathrm{E}^{\circ}$ red value for $\mathrm{HO}_{2}^{-}$is $+0.878 \mathrm{~V}$ and the value of $\mathrm{E}^{\circ}$ red for $\mathrm{MnO}_{4}^{-}$is $+0.59 \mathrm{~V}$ [22], hence it can be said that sodium percarbonate is better at receiving electrons and is a better oxidizing agent compared to potassium permanganate because of the higher value of its $\mathrm{E}^{\circ}$ red. Higher value of $\mathrm{E}^{\circ}$ red causes the $\mathrm{E}^{\mathrm{o}}$ cell value when using catholyte Sodium percarbonate to be higher in comparison to the $\mathrm{E}^{\mathrm{o}}$ cell value when using catholyte potassium permanganate. Consequently, the potential difference on SMDC system using NP is higher than SMDC system with $\mathrm{KMnO}_{4}$. Potential difference stimulates the migration of ions and the flow of electrons [23] thus, the higher the potential difference, the higher the electron transferred by the bacteria.

Furthermore, the negative salt removal in the DCathode chamber when using $\mathrm{KMnO}_{4}$ is possibly due to the accumulation of potassium ions or a potassium cross over from the cathode chamber to the DesalinationCathode chamber by back-diffusion [4].

\subsection{Specific Desalination Rate and Total Desalination Rate}

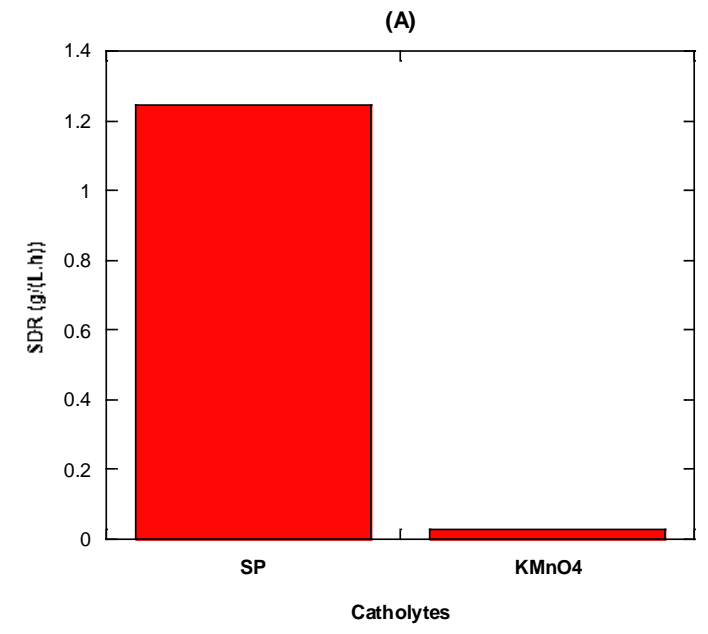

(B)

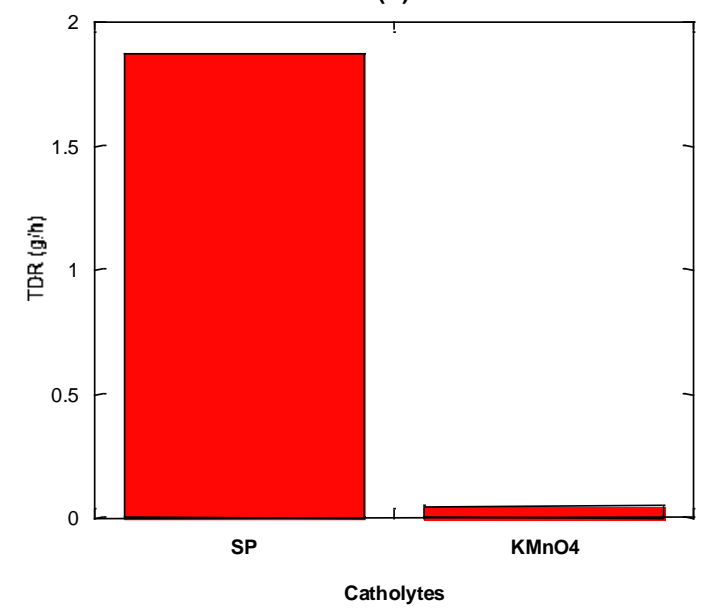

Fig. 7. (a) Specific desalination rate (SDR) and (b) Total desalination rate (TDR) with different Catholytes SP and $\mathrm{KMnO}_{4}$ at the end of one desalination cycle $(\mathrm{t}=50 \mathrm{~h})$.

The comparison between the two catholytes Sodium percarbonate $(\mathrm{SP})$ and Potassium permanganate $\left(\mathrm{KMnO}_{4}\right)$ shows that catholyte SP has higher SDR value compared to $\mathrm{KMnO}_{4}$ as shown in Fig. 7(a). The SDR of SMDC using $\mathrm{SP}$ and $\mathrm{KMnO}_{4}$ as the catholytes are $1.2469 \mathrm{~g} /$ (L.h) and $0.0296 \mathrm{~g} /$ (L.h) respectively. According to theory stated by Chen et al., 2011, SDR is the salt removal based on salt solution volume, thus the volume of desalination chamber [3]. If it had to follow that theory, the SDR when using both catholytes supposed to be similar since the volume of the desalination chambers is equal for both cases. However, it can be seen that in this research, there is a significant difference in the SDR value which is higher when SP is used as catholyte than $\mathrm{KMnO}_{4}$.

Based on Eq. (3), the SDR value is also influenced by the desalination ratio which is influenced by the conductivity of the salt water in the desalination chamber as well besides the volume of the desalination chamber. Where lower conductivity results in higher SDR. Based on theory, conductivity is inversely proportional to voltage; the main impact on the voltage produced in the MDC was the decrease in the conductivity of the solution in the desalination chamber over the full cycle [4]. The SDR is higher using SP because the desalination ratio $\eta$ is higher 
due to lower conductivity of the salt water at the end of the desalination cycle. Lower conductivity can be achieved by higher voltage and it is known that the use of SP results in higher voltage compared to $\mathrm{KMnO}_{4}$ according to Eq. (6) and (7). Thus, the higher reduction voltage, the higher the value of SDR obtained.

Furthermore, Fig. 7(b) shows that catholyte SP has higher TDR value compared to $\mathrm{KMnO}_{4}$. The TDR of SMDC using SP and $\mathrm{KMnO}_{4}$ as the catholytes are 1.8704 $\mathrm{g} / \mathrm{h}$ and $0.0444 \mathrm{~g} / \mathrm{h}$ respectively. The influence of the desalination ratio on the TDR is the same as that on the SDR based on Eq. (4); the higher the desalination ratio is, the higher the TDR obtained.

\section{5. $\mathrm{pH}$ Change}

\subsection{1. pH Cathode Chamber}

Table 2 describes the data of $\mathrm{pH}$ obtained in the cathode chamber from the SMDC experiment that has been done.

Table 2. Result of $\mathrm{pH}$ change in the cathode chamber.

\begin{tabular}{|c|c|c|c|}
\hline \multirow{2}{*}{ Experiment } & \multicolumn{3}{|c|}{ Catholyte } \\
\hline & pH Initial & pH Final & $\Delta \mathrm{pH}$ \\
\hline \multicolumn{4}{|c|}{ Sodium Percarbonate (SP) } \\
\hline $0.05 \mathrm{M}$ & 10.8 & 11.0 & 0.2 \\
\hline $0.1 \mathrm{M}$ & 11.4 & 11.5 & 0.1 \\
\hline $0.15 \mathrm{M}$ & 10.8 & 10.9 & 0.1 \\
\hline $0.2 \mathrm{M}$ & 11.0 & 11.1 & 0.1 \\
\hline \multicolumn{4}{|c|}{ Potassium Permanganate $\left(\mathrm{KMnO}_{4}\right)$} \\
\hline $0.15 \mathrm{M}$ & 7.25 & 8.20 & 0.95 \\
\hline
\end{tabular}

From the result obtained in the table above, it can be seen that in the cathode chamber, there is an overall increase in $\mathrm{pH}$. Based on the table, when Sodium percarbonate (SP) is used as a catholyte, it causes only a slight change of $\mathrm{pH}$ between 0.1-0.2 while when $\mathrm{KMnO}_{4}$ is used as a catholyte it causes a greater change of $\mathrm{pH}$ that reaches \pm 1.0 . This result confirms that Sodium percarbonate is a better catholyte in maintaining $\mathrm{pH}$ stability compared to $\mathrm{KMnO}_{4}$ even without the addition of buffer solution.

According to theory, one of the most advantageous aspects of using SP as a catholyte is due to its property of being able to provide an excellent buffer capacity for $\mathrm{pH}$ stabilization [12]. An increase in $\mathrm{pH}$ in the cathode chamber occurs due to the accumulation of hydroxide in the cathode chamber due to oxygen reduction, hence increasing $\mathrm{pH}$ within the cathode chamber [24]. In cathode chamber, there is a dissociation of SP when dissolved in water, which represented in the equation below.

$$
2 \mathrm{Na}_{2} \mathrm{CO}_{3} \cdot 3 \mathrm{H}_{2} \mathrm{O}_{2} \rightarrow 4 \mathrm{Na}^{+}+2 \mathrm{CO}_{3}^{2-}+3 \mathrm{H}_{2} \mathrm{O}_{2}
$$

Sodium percarbonate dissociate into $4 \mathrm{Na}^{+}+2 \mathrm{CO}_{3}{ }^{2-}$ $+3 \mathrm{H}_{2} \mathrm{O}_{2}$ when dissolved in water and $\mathrm{H}_{2} \mathrm{O}_{2}$ is an oxidizing agent or an electron acceptor which is further reduced forming $\mathrm{OH}^{-}$ions. These $\mathrm{OH}^{-}$ions will bond with the $\mathrm{Na}^{+}$ions from the adjacent Desalination chamber forming $\mathrm{NaOH}$ which causes the $\mathrm{pH}$ in the cathode to increase. The transport of alkali-metal cations from the DCathode chamber towards the cathodic chamber increases the $\mathrm{pH}$; due to the concentration gradient between the cathodic chamber and its adjacent desalination chamber [25]. Furthermore, this increase of $\mathrm{pH}$ can also be caused by the $\mathrm{OH}^{-}$that bonds with other $\mathrm{Na}^{+}$ions produced from the decomposition of SP [26]. However, fortunately Sodium percarbonate has a natural buffering capacity that comes from the bicarbonate ions $\left(\mathrm{HCO}_{3}^{-}\right)$, where $\mathrm{OH}^{-}$will bind to it forming $\mathrm{CO}_{3}{ }^{2-}$ which serves as $\mathrm{pH}$ buffering system.

It can be seen that $\mathrm{pH}$ change in $\mathrm{SP} 0.05 \mathrm{M}$ is greater than SP $0.1 \mathrm{M}, 0.15 \mathrm{M}$, and $0.2 \mathrm{M}$. This is because the higher the concentration of SP, the higher its buffer capacity [12]. In comparison with SP, an increase in $\mathrm{pH}$ is relatively significant when using $\mathrm{KMnO}_{4}$ as catholyte; there is an increase of $\mathrm{pH}$ as much as 1.0. This might be caused by the reaction between buffers $\mathrm{KH}_{2} \mathrm{PO}_{4} / \mathrm{K}_{2} \mathrm{HPO}_{4}$ with $\mathrm{NaOH}$ which can be shown in the reaction eq. (9) below.

$$
\mathrm{NaOH}+\mathrm{KH}_{2} \mathrm{PO}_{4} \rightarrow \mathrm{NaHPO}_{4}+\mathrm{KOH}
$$

The uses of buffer $\mathrm{KH}_{2} \mathrm{PO}_{4} / \mathrm{K}_{2} \mathrm{HPO}_{4}$ in SMDC system based on the reaction above will produce a strong base $\mathrm{KOH}$ which causes an increase in $\mathrm{pH}$ of cathode chamber greater than SP [26]. Moreover, KMnO4 itself does not have a natural buffering capacity in contrast to Sodium percarbonate as a catholyte in SMDC system.

\subsection{2. $\mathrm{pH}$ Anode Chamber}

\begin{tabular}{|c|c|c|c|}
\hline \multirow[b]{2}{*}{ Experiment } & \multicolumn{3}{|c|}{ Anolyte } \\
\hline & $\mathrm{pH}$ Initial & $\begin{array}{l}\mathrm{pH} \\
\text { Final }\end{array}$ & $\Delta \mathrm{pH}$ \\
\hline \multicolumn{4}{|c|}{ Sodium Percarbonate (SP) } \\
\hline $0.05 \mathrm{M}$ & 6.00 & 4.20 & -1.8 \\
\hline $0.1 \mathrm{M}$ & 6.95 & 5.35 & -1.6 \\
\hline $0.15 \mathrm{M}$ & 6.75 & 5.20 & -1.55 \\
\hline $0.2 \mathrm{M}$ & 6.40 & 5.50 & -0.9 \\
\hline \multicolumn{4}{|c|}{ Potassium Permanganate $\left(\mathrm{KMnO}_{4}\right)$} \\
\hline $0.15 \mathrm{M}$ & 6.20 & 4.90 & -1.3 \\
\hline
\end{tabular}

Table 3. Result of $\mathrm{pH}$ change in the Anode Chamber.

Based on the result obtained in the table above, there is an overall decrease in $\mathrm{pH}$ within the anode chamber. It is observed that $\mathrm{pH}$ experienced a decrease with a range of 0.9-1.8. It is known that phosphate buffer $\mathrm{pH} 7$ is added to the substrate tofu wastewater before the experiment 
begins in order to make the $\mathrm{pH}$ not to be too acidic to begin with. The reason being is because tofu wastewater is acidic with $\mathrm{pH}$ about 4-5 since during the tofu preparation acetic acid (vinegar) is added for coagulation [27]. It can be seen that even with the addition of buffer with 1:1 ratio, the substrate still have a slight acidic characteristic.

This decrease in $\mathrm{pH}$ that occurs in the anode chamber is due to the bacteria activity in the anode chamber. As the bacteria release protons into solution, the $\mathrm{pH}$ decreases resulting in protonation in the anode chamber [5]. In other words, as the desalination process occurs over time, protons accumulate as a result of microbial respiration causes the $\mathrm{pH}$ in the anode chamber to decrease and becoming more acidic [24].

\section{Conclusion}

The conclusions that can be drawn from this research are as follows:

1. With the use SMDC system and tofu wastewater as a substrate, the optimum concentration of Sodium percarbonate obtained is equal to $0.15 \mathrm{M}$ with salt removal of $1.77 \%$ and $0.82 \%$ in the DesalinationCathode and Desalination-Anode Chambers respectively. Thus, a total of $2.59 \%$ salt removal.

2. Catholyte Sodium percarbonate shows better desalination performance compared to catholyte Potassium permanganate. SP obtained a total salt removal equal to $2.59 \%$, and a reduction of the salinity from $29.03 \mathrm{~g} / \mathrm{L}$ to $28.52 \mathrm{~g} / \mathrm{L}$. Whereas $\mathrm{KMnO}_{4}$ obtained a total salt removal of $0.23 \%$ only in the DAnode Chamber, with a reduction in the salinity from $27.18 \mathrm{~g} / \mathrm{L}$ to $27.12 \mathrm{~g} / \mathrm{L}$.

3. Catholyte Sodium percarbonate obtains higher SDR and TDR of $1.2469 \mathrm{~g} /(\mathrm{L} . \mathrm{h})$ and $1.8704 \mathrm{~g} / \mathrm{h}$ respectively compared to $\mathrm{KMnO}_{4}$ as a catholyte.

\section{Acknowledgement}

The authors would like to acknowledge the grant PIT-

9 Universitas Indonesia with Grant number NKB-0791/UN2.R3.1/HKP.05.00/2019 for supporting this research.

\section{References}

[1] UNESCO, "The United Nations world water development report 2018," 2018. [Online]. Available: https://unesdoc.unesco.org/ark:/48223/pf0000261 424

[2] P. Csaba and J. Csaba, Water Resources Management and Water Quality Protection. 2011.

[3] X. Chen, X. Xia, P. Liang, X. Cao, H. Sun, and X. Huang, "Stacked microbial desalination cells to enhance water desalination efficiency," Environmental Science \& Technology, vol. 45, no. 6, pp. 2465-2470, 2011.

[4] X. Cao, X. Huang, P. Liang, K. Xiao, Y. Zhou, X. Zhang, and B. E. Logan, "A new method for water desalination using microbial desalination cells," Journal of Environment Science Technology, vol. 43, pp. 7148- 7152, 2009.
[5] M. Mehanna, T. Saito, J. Yan, M. Hickner, X. Cao, X. Huang, and B. E. Logan, "Using microbial desalination cells to reduce water salinity prior to reverse osmosis," Energy \& Environmental Science, vol. 3, pp. 1114-1120, 2010.

[6] H. Luo, P. Xu, T. M. Roane, P. E. Jenkins, and Z. Ren, "Microbial desalination cells for improved performance in wastewater treatment, electricity production, and desalination," Bioresource Technology, vol. 105, pp. 60-66, 2011.

[7] Y. Qu, Y. Feng, X. Wang, J. Liu, J. Lv, W. He, and B. Logan, "Simultaneous water desalination and electricity generation in a microbial desalination cell with electrolyte recirculation for $\mathrm{pH}$ control," Bioresource Technology, vol. 106, pp. 89-94, 2011, doi: 10.1016/j.biortech.2011.11.045.

[8] Y. Kim and B. E. Logan, "Series assembly of microbial desalination cells containing stacked electrodialysis cells for partial or complete seawater desalination," Environmental Science \& Technology, vol. 45, pp. 5840 - 5845, 2011.

[9] K. Zuo, J. Cai, S. Liang, S. Wu, C. Zhang, P. Liang, and $\mathrm{X}$. Huang, "A ten liter stacked microbial desalination cell packed with mixed ion-exchange resins for secondary effluent desalination, Environmental Science \& Technology, vol. 48, no. 16, pp. 9917-9924 2014.

[10] A. Ziaedini, H. Rashedi, E. Alaie, and M. Zeinali, "Performance assessment of the stacked microbial desalination cells with internally parallel and series flow configurations," Journal of Environmental Chemical Engineering, vol. 6, no. 4, pp. 5079-5086, 2018.

[11] M. Faisal, A. Gani, F. Mulana, and H. Daimon, "Treatment and utilization of industrial tofu waste in Indonesia," Asian Journal of Chemistry, vol. 28, no. 3, pp. 501-507, 2016.

[12] C. Forrestal, Z. Huang, and Z. J. Ren, "Percarbonate as a naturally buffering catholyte for microbial fuel cells," Bioresource Technology, vol. 172, pp. 429-432, 2014.

[13] G. C. Gil, I. S. Chang, B. H. Kim, M. Kim, J. K. Jang, H. S. Park, and H. J. Kim, "Operational parameters affecting the performannce of a mediator-less microbial fuel cell," Biosens. Bioelectr., vol. 18, pp. 327334, 2003.

[14] K. S. Jacobson, D. M. Drew, and Z. He, "Use of a liter-scale microbial desalination cell as a platform to study bioelectrochemical desalination with salt solution or artificial seawater," Environmental Science \& Technology, vol. 45, pp. 4652-4657, 2011.

[15] Q. Y. Ping, B. Cohen, C. Dosoretz, and Z. He, "Long-term investigation of fouling of cation and anion exchange membranes in microbial desalination cells," Desalination, vol. 325, pp. 48-55, 2013.

[16] Q. Ping, O. Porat, C. Dosoretz, and Z. He, "Bioelectricity inhibits back diffusion from the anolyte into the desalinated streams in microbial desalination cells," Water Research, vol. 88, pp. 266$273,2016$. 
[17] B. E. Logan, B. Hamelers, R. Rozendal, U. Schröder, J. Keller, S. Freguia, P. Aelterman, W. Verstraete, and K. Rabaey, "Microbial fuel cells: Methodology and technology," Environ. Sci. Tecbnol., vol. 40, pp. 51815192, 2006.

[18] V. G. Gude, B. Kokabian, and V. Gadhamshetty, "Beneficial bioelectrochemical systems for energy, water, and biomass production," J. Microb. Biochem. Technol. S, vol. 6, pp. 1-14, 2013.

[19] A. Kaabi, M. Tliha, Y. B. Belgacem, A. Dhahri, C. Khaldi, and J. Lamloumi, "Influence of electrolyte concentration on the electrochemical characteristics of $\mathrm{LaGaO} 3$ perovskite oxide as novel anode material for Ni/MH batteries," Ceramics International, vol. 43, no. 17, pp. 15743-15746, 2017, doi: 10.1016/j.ceramint.2017.08.136.

[20] R. H. Petrucci, F. G. Herring, J. D. Madura, and C. Bissonette, General Chemistry: Principles and Modern Applications, 10th ed. Ontario: Pearson Canada, 2010.

[21] E. Wiberg and N. Wiberg, Inorganic Chemistry. Cambridge: Academic Press, 2001.

[22] S. You, Q. Zhao, J. Zhang, J. Jiang, and S. Zhao, “A microbial fuel cell using permanganate as the cathodic electron acceptor," Journal of Power Sources, vol. 162, pp. 1409-1415, 2006.

[23] A. Carmalin Sophia, V. M. Bhalambaal, E. C. Lima, and M. Thirunavoukkarasu, "Microbial desalination cell technology: Contribution to sustainable waste water treatment process, current status and future applications," J. Environ. Chem. Eng., vol. 4, pp. 3468 3478, 2016.
[24] S. Sevda, H. Yuan, Z. He, and I. M. Abu-Reesh, "Microbial desalination cells as a versatile technology: Functions, optimization and prospective," Desalination, vol. 371, pp. 9-17, 2015.

[25] H. Pradhan and M. M. Ghangrekar, "Multi-chamber microbial desalination cell for improved organic matter and dissolved solids removal from wastewater," Water Science and Technology, vol. 70, no. 12, pp. 1948-1954, 2014.

[26] E. D. Kamila, "Penggunaan Air Lindi dan Natrium Perkarbonat sebagai: Penggunaan Air Lindi dan Natrium Perkarbonat sebagai Elektrolit Berpenyangga Alami dalam Sistem Microbial Desalination Cell," thesis, Depok: Program Studi Teknologi Bioproses, Fakultas Teknik, Universitas Indonesia, 2016.

[27] M. Faisal, F. Mulana, H. Daimon, and I. Machdar, "Potential renewable energy from tofu processing waste in Banda Aceh City, Indonesia," Asian Journal of Chemistry, vol. 26, p. 6601, 2014, doi: 10.14233/ajchem.2014.16728. 

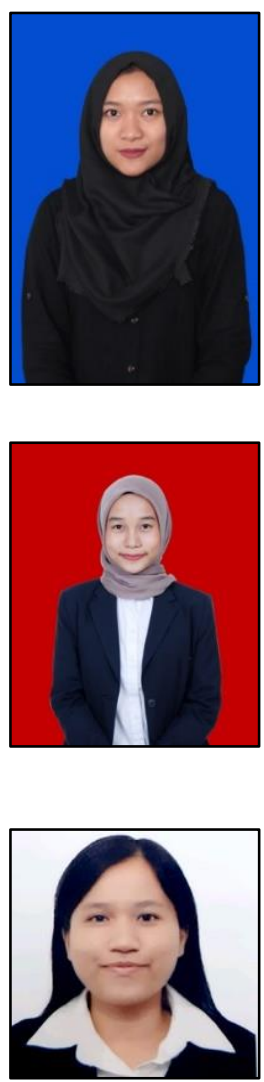

Raissa Maulina was born in Was born in jakarta, Indonesia on July 7th 1997. She received the Bachelor of Engineering (S.T.) degree in chemical engineering from Universitas Indonesia, Depok, West Java, Indonesia, in 2019.

As for her working experience, she was a staff intern in Health safety Environment division at PT. Halliburton, Oil and Gas company in Tangerang.

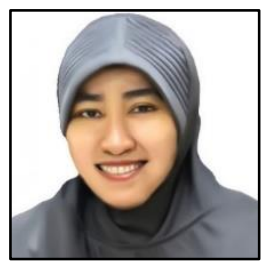

Tania Surya Utami was born in Pekanbaru, Riau, Indonesia on May 12 ${ }^{\text {th }}, 1974$. She received her bachelor degree in Gas and Petrochemical Engineering from Universitas Indonesia in 1997, master and doctoral degree from Chemical Engineering Universitas Indonesia in 2001 and 2011 respectively.

Dr. Tania Surya Utami, S.T., M.T., is a lecturer of Chemical Engineering, Faculty of Engineering, University of Indonesia since 1998. She teaches chemical engineering's subject such as heat transfer, engineering economic, and physic-chemistry.

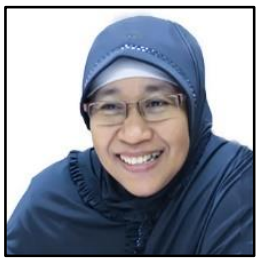

Rita Arbianti was born in Bukittinggi, West Sumatra, Indonesia on February 2nd, 1969. She graduated with a BSc in Gas and Petrochemical Engineering from Univeristias Indonesia and she gained a Master in Chemistry Science from Universitas Indonesia.

Rita Arbianti is a lecturer of Chemical Engineering, Faculty of Engineering, University of Indonesia since 1995. In 2006, she became a Head of Basic Chemistry Laboratory, Chemical Engineering Department UI.

Ir. Rita Arbianti, M.Si received "Satyalancana Karya Staya UI” Achievement in 2007.

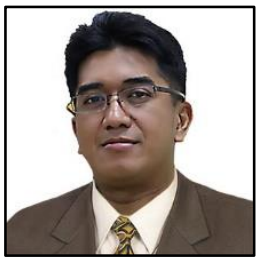

Heri Hermansyah was born in Sukabumi, West Java, Indonesia on January 19th, 1976. He graduated with a BSc in Chemical Engineering from Universitas Indonesia. He gained a Master also in Chemical Engineering from Tohoku University, Japan. He hold a doctoral programme in Chemical Engineering from Tohoku University, Japan.

Heri Hermansyah is a lecturer of Chemical Engineering, Faculty of Engineering, University of Indonesia since 2006.

Prof. Dr. Heri Hermansyah, S.T., M.T., presently, he became a Head of Bioprocess Technology Study Program and Head of Industrial Bioprocess Engineering Research Group. 